\title{
The Image as a Para-textual Element in Willa Cather's My 'Antonia
}

\section{Dr. Amany Abdullah Abdel-Aziz Eldiasty *}

\section{E-MaiL: amanyeldiasty@du.edu.eg}

ABSTRACT
ARTICLE INFO
Received 2020-08-23
Accepted 2020-11-24
Keywords 'Antonia,
My art,
Visual Theory,
Wittgenstein's
Picture paratexts

ARTICLE INFO

Received 2020-08-23

Accepted 2020-11-24

\section{Keywords}

Visual art,

Wittgenstein's

paratexts
The paper tackles the role played by images in Willa Cather's novel My Antonia. It demonstrates that the images used in the novel serve a literary function that is crucial to understand the novel. Depending mainly on the definition of a paratext as an element that complements the texts, the paper proposes that images in the novel constitute one such element. The use of images in My Antonia represents a technical innovation that Willa Cather (1876-1947) employed in the novel. The paper analyzes the text from two vantage points that are presented simultaneously to prove that they complement each other. Within this context, many factors are taken into consideration: time, characterization and viewers. The image and the word are analyzed together to reach a dialectical vision of an image text. The paper proves that Cather employs visual art in her novel to deny a centralized vision or a totalized experience.

\footnotetext{
${ }^{*}$ Lecturer, Damietta Faculty of Arts, Egypt
} 


\section{The Image as a Para-textual Element in Willa Cather's My 'Antonia}

So words still dominate. But yes, visual images, successive images, play an enormous part in our lives today, larger than ever before. Those images can show the same insecure inventiveness as do our manipulations of words.(Hoggart, 2020[1994]: 3)

This paper tackles Willa Cather's My 'Antonia(1994)[1918], a masterpiece praised for enlivening the American West, as an innovative piece of visual art. Cather uses eight visual images in $M y$ 'Antonia which offer different possibilities for meaning making. Within the interdisciplinary approach and based on Ludwig Wittgenstein's Picture Theory of Representation, the paper aims at examining the distinction between visual representation and textual representation, considering notions of time, context and characterization. It examines the binary theory of picture and text and replace that relation with a dialectical picture, image text. It also reveals the significance of the novel's pictorial imagery through exploring a third aspect of representation. As a result, images appear as para-textual elements that enrich meaning and enlarge the literary context. Briefly speaking, the novel revolves around Antonia Shimerda and Jim Burden through the eyes of Jim as he narrates the main bulk of the events reminiscing his memories as a child till he becomes a youth at the end.

Gérard Genette opines that things that are presented as crucial elements in a literary work, but still are not part of the text, are called para-texts. Commenting on the importance of such things, Genette writes, "One does not always know if one should consider that they belong to the text or not, but in any case they surround it and prolong it, precisely in order to present it, in the usual sense of this verb, but also in its strongest meaning: to make it present, to assure its presence in the world" (Genette,1991: 261; Genette,1997). These things vary to include a title, an epigraph, a preface, an "epilogue, footnotes, dust 
jacket commentaries, photographs" or any illustrations (Genette,1991,1997; see also Onega, 2006: 277). Hence, one could easily regard the images used by Cather in her novel My Antonia one of these paratexts.

The ability to explain a narrative or an idea pictorially is one of the fundamental activities of illustrations. Although it is an ancient medium with a rich history, the field of illustration is a dynamic and contemporary means of interpretation and communication which conveys ideas and messages with impressively meaningful imagery. In a novel, images and words should work together to create stories. In this way, the reader thinks about the art of storytelling as inserting a picture which is considered a stimulus for storytelling. Since interpreting a text must take into consideration plot development, mood of the narrator and pace of the narrative, the text and image should juxtapose to create specific emotions and to elucidate and strengthen the theme discussed.

Visual strategies for telling stories have witnessed a recently gradual development across the globe. In his book A Concise History of Modern Painting, Sir Herbert Read(1968) traces the development of visual experience that is at the core of painting. He, furthermore, illustrates how this is connected with the general movement of thought and sensibility during the same period. Painters tend to represent the world 'as it really is'. However, interpretation intervenes between the visual event and the act of realizing the vision. This kind of perception is liable to variety of vague meanings.

To explore visual art in Cather's My 'Antonia, I employ Ludwig Wittgenstein's Picture Theory of Representation. It states that "a picture represents or depicts a subject when and only when the parts of the picture have the same logical multiplicity as the parts in the subject represented, and appropriate rules are assumed relating picture parts and relations to the parts and relations of the subject represented" (Carney,1981: 181). A picture, according to Wittgenstein, is divided 
into two parts: the elements of the picture and the form or structure of that picture. While the "elements of the picture are representatives of objects", the structure of the picture represents the way in which those objects are combined (Wittgenstein,1986). The building blocks of a picture are its elements which are much often viewed as line, shape, space, forms, color and texture. Such elements are the tools that will be used in analyzing Benda's drawings in Cather's My 'Antonia.

A picture has an identical structure to the structure of some possible fact. The structure of a picture can represent the structure of a state of affairs which is a combination of objects. However, "[a] picture can present relations which do not exit [...]. How can a non-existent connection between objects be possible? How is that possible? [...] [T]here is supposed to be a problem for the Picture Theory (for strong isomorphism) in explaining the possibility of falsehood: in explaining how a proposition can describe relations between objects, which fail to exist" (160). A picture depicts reality by representing a possibility of existence and non-existence of states of affairs. The analogy with pictures ought to provide a complete solution to the problem of truth. Such a definition entails the study of the reliability and unreliability theory of narration to be applied on Cather's My 'Antonia.

In his Philosophical Investigation, Wittgenstein (1986) demonstrates that the "mental picture is the picture which is described when someone describes what he imagines"(367). This necessitates that the mental image should be the same as the visual image projected by the artist. In his article, "Wittgenstein and Aesthetics: What is the language of Art", Lundquist (1999) defines what an artist is and what the features of an artist are: 
Who is the artist[...]? The way that one becomes an excellent artist is the same as one becomes a great thinker or speaker or scientist, and yet, because the artist works in a medium that is impossible to translate into language, it is more difficult to define him. Artists learn a vocabulary much the same way that we learn our language-through imitation, practice, and eventually study of its structure. Only after gaining an understanding and developing skills can one begin to create truly meaningful art. These skills are very public and are not nearly as mysterious to us as the meaning of art because in many cases, the study of technique has been transcribed into words. (par. 11)

Some techniques are followed to draw suitable illustrations to convey certain meanings. Artists know how to move the body in certain ways to get certain effects. They cannot paint relations between light and shade. Yet, according to Cather, artists can only "paint some emotions they gave him, some man-made arrangement of them that happens [sic] to give him personal delight"(1988: 124). That much often repeated pleasure in a painter becomes a "style", a way of seeing and feeling things, which is a favorite mood (124). Cather explains that light is much the same in every country, yet Leonardo, for instance, painted what he got out of light — what it did to him"(124). Likewise, in literature writers cannot write of abstract concepts like love, hatred, jealousy, depression; writers only touch these things as they affect the characters in the story. Writers project their thoughts and experiences about such concepts. In such a way, a writer can use pictures to display his/her views and a variety of others concerning these abstract ideas. 
Writers and artists use several narrative innovations. Such innovations, according to Petersen (2011), "create a pictographic shorthand, making the action easier to read"(7). Similar to the use of synecdoche in language, "[a]n opponent may be represented only by a gun, or a horse by its tracks, and sometimes the repetition of a figure is a way of describing two different events happening to the same person over time"(7). In Cather's case, though she creates pictorial shorthand for her text to facilitate grasping the meaning, a gun represents a gun as a tool of hunting or ending one's life and a horse represents an animal as a means of transportation or as a tool of ploughing in the context. Yet the sun represents many things.

Though Cather is so careful to distance herself from art that she proclaims a break with the old traditions in many interviews, her comments are evidence of her own desire to make her art new. Cather, in effect, borrowed, adopted and adapted some tools and techniques belonging to the realm of visual art, which actually made her fictional writing look new. This particular use of visual elements is what places her with the scope of the modern. For Cather, the artist in order to present his/her most haunting subject in a good way, s/he has to try "different lightings and attitudes with his/her subject to catch the one that presents it more suggestively than any other"(Cather,1988:51). She realizes the necessity of light for creating feelings and adding emotional dimensions in her characters. For instance, Antonia's heroic character is so frequently associated with the light of the sun that all differences between them seem to disappear; it is as if Antonia merges into the sun and the sun is "an extension" of her (Bloom,1962: 36).

Throughout the course of the novel, Antonia is fond of the sun. She is used to throwing off her sunbonnet in the orchard as if she wants to be fully in touch with the sunlight (Cather,1994[1918]:128). After her father's death, she sadly tells Jim that she has no time to learn while "look[ing] off the red streak of dying light, over the dark prairie" (118). "Dying light" here signifies Antonia's ardent desire to get an education 
cannot be achieved because she shoulders the responsibilities of her family after her dad commits suicide. Near the end of the novel, when her lover, Donovan, disgraces and abandons her, Antonia, alone, "sun[s] herself for hours" (251) as if she is getting power and strength from the sun to go ahead with her life and manage her trouble. Yet, Cather refers to the limitations of an artist or a painter: "Nobody can paint the sun, or sun light. He can only paint the tricks that shadows play with it, or what it does to forms. He cannot even paint those relations of light and shade"(123). Like a painter, the artist uses his memories as well as his colors till s/he "emerges with much that is more or less happy experimenting" (Cather,1988 51). Memories are like colors in paintings, but the artist must arrange them. In My Antonia, Jim is selected to narrate his memories with Antonia and the Shimerdas. Cather herself is so close to her subjects that readers feel that she is remembering rather than recreating experience.

As for beauty of style, Cather is against too much ornament and excessive details in novels. Instead, she calls for an organic kind of beauty which stems from "disfurnishing" the novels, throwing all the extra furniture out of the window. In her essay entitled "The Novel Démeublé" (1922), she describes her prose style as "unfurnished". Cather distinguishes between two kinds of beauty. To elaborate on this matter, Cather quotes Gilbert Murray's illustration of these types: 'beauty which comes from rich ornamentation; like the splendor one might admire on a Chinese junk ... then there is the beauty of a modern yacht, where there is no ornamentation at all' (Cather,1949: xviii). Cather appreciates the second type of beauty since the pleasure felt in such beauty stems from the fact that "each line of the craft is designed for one purpose, so that it has an organic, living simplicity and directness"( xviii). In the same vein, every word in her own fiction is written to serve a specific purpose. Similarly, every line in the pictures selected in her work serves a specific function as will be illustrated later. 
Cather is much influenced by Dutch painting. The idea of experimenting with form comes to her when she was visiting an art exhibit of old and modern Dutch painting. At the age of twenty two, Cather encountered impressionistic style of painting at the University of Nebraska's Haydon Art Club Exhibit in 1895 (Cather,1988: 31). She knows quite well the conventions of Western art due to her professional experience as an editor at McClure's. Moreover, her several travels to England and France widen her knowledge of visual arts, which becomes a great resource for her to incorporate in her novels. Painting influences Cather's portrayal of her fictional characters. She not only uses painterly techniques and new devices which she experiments with the novel form, but she is also inspired by some of those paintings in her portrayal of some of her characters as on The Professor's House. However, in My 'Antonia, Cather commissions W T Benda (18731948), so widely known for painting Western subjects and pictorial series, to draw pictures based on Jim's story. She designs the sketches and arranges their inclusion herself. Benda's illustrations attract Cather's attention as an editor of Mcclure's magazine. Many of them appear in ten separate stories. Much of Benda's previous work is replete with heavily shaded style, yet what Cather seeks is brevity and simplicity.

Though illustrations are not common in fiction, except in children's literature, they "are without question, an integral component of [My Antonia], and considering them in succession provides a useful introduction to the book" (Urgo,2003: 26). In series of exchanged letters with her first publisher, Houghton Mifflin, Cather insists that My 'Antonia's illustrations be regarded as an integral part of the text (Stout,2007: 108). She herself tries to draw the illustrations. When she meets Benda, she shows him her plain sketches. Cather is influenced by a great deal of similarity between Benda and Antonia, the titular character in My 'Antonia. Like 'Antonia, Benda is a Bohemian American who lives in the West. Cather considers him ideally appropriate to the task of providing a pictorial counterpart to Jim's 
narrative. She always wants to be "an author who is out of it"(Leddy,2009: 1).

Cather acknowledges divergence from the conventional form of a novel to create the true art she aspires to write. With this end in mind, Cather's My 'Antonia is "made up of little, everyday happenings for the most part, for such events [make up] the bulk of most people's lives" (Woodress, 1987: 290). Commenting on the pattern of her novel, Cather shows "no love affair, no courtship, no marriage, no broken heart, no struggle for success"(290), believing that these issues would "ruin" her material if she put them in the "usual fictional pattern". Benda lets Cather achieve this ambition since he develops the new conventions demanded by his strange new world. Cather mixes two different media; she sets art in context. She successfully manages to enhance new forms. Instead of "telling the story of an artist's life or of a period in art history" (Carrier,2003: 81), Cather takes the other way round: she employs art in telling stories, using pictures as a tool for storytelling.

For reasons of clarity and focus of the story, Cather provides some pictures to her "cyclic" narrative (Petersen,2011: 18), one that is dependent on words for comprehension and uses book illustrations alongside the text. These illustrations, according to Jean Schwind (1985), are "silent supplement to the text and needed corrective to the romantic bias of Jim's story" (59). These pictures are more likely to be considered a means for storytelling, illuminating narrative details. My Antonia is replete with visual details as well as visual art. Cather's details are enclosed with empty space. Through preferring to "disfurnish" her novel-removing all useless pieces of furniture, she lets her reader's eye focus on just the selected pieces that she kept. Readers notice Cather's visual details in sentences and phrases such as "trailed along the prairie"(59), "amber sunlight"(58),"dragging his feet along as if he had no purpose"(60),"chirp faintly"(60), "raced my shadow home"(62). In this way, she engages the readers in visualizing 
the atmosphere of events, something which is part of Cather's creative vision.

In My Antonia, Cather presents a multiple frame narrative art, which means-according to Roberts Petersen-"each picture in the sequence represents a scene and each subsequent picture is related through a common story or related story" (Peterson,2011: 16). Each frame represents an autonomous moment in the overall much like a series of monoscenic pictures. On the other hand, when different commentators try to interpret one painting, we-according to David Carrier-may wonder "whose account is most true to the object" because each interpretation comes embedded in a distinctive context (Carrier,2003: 111). Cather diverts from the conventional form of the novel to create true art. In her preface to Stephen Crane's Wounds in the Rain, Cather(1988:69) believes that one could compare prose and painting. Moreover, Murphy emphasizes that Cather learned from Henry James "a persistently pictorial quality in her writing that implies a shared sense of the affinity between the arts of the novelist and of the painter(Kaufman and Millington, 2015: Xv-Xvi)

Cather lets the deprived sector of society, the immigrants, be heard in My 'Antonia. She presents their dreams as well as their suffering and perseverance. Within the story of Antonia and Jim's friendship there are many stories of specific details which, sometimes, seem to have nothing to do with the main events in the novel. Yet these stories serve to let us know the cycle of all characters both men and women coming from different parts of the world to the New Land, carrying their own stories, dreams and aspiration, and participating in creating new stories, suffering, perseverance, and even paying their own lives as a price for their dreams or for achieving others' dreams. Mr. Shimerda's committing suicide is a case in point. Cather also gives voice to marginal people through introducing the incident of the talented Negro pianist, Blind d'Arnault, who comes to town and breaks life monotony by giving a musical performance. 
Cather experiments with the novel form, drawing on life and art. She carefully uses selected images to create a rich portrayal of the New Land. She achieves a realistic portrayal of life through depicting the shocking realities of immigrant life, and how their lives are broken by the hardness and cruelty of wild life. Some prove resilient and strong, triumphing over struggle such as the story of Antonia, and that of Pavel. For instance, Pavel, a Russian immigrant, on his deathbed reveals that he saved his own life and that of his companion, Peter, by throwing a bride and groom to the attacking wolves. This incident adds much to the astonishment of both Antonia and Jim. It is full of drama and invokes the colour of a foreign setting and reveals a mysterious memory of the past. Other immigrants prove weak, dejected and defeated such as Mr. Shimerda as the analysis of Benda's drawing will illustrate. Cather emphasizes the significant role that art plays in one's life; it creates an alternative reality, thus livening and improving one's life. It is clear through the incident of the Blind pianist who amuses people by making a musical performance.

Cather combines traditions and new perceptions. She uses pictorial techniques to strengthen and invigorate her literary style. Her style is characterized by both external simplicity and internal complexity. In her simple style, one word may suggest so many things. She uses directly explicit sentences; yet her language is filled with images and metaphors. She does not describe for mere description; she describes to imprint meanings on the minds of her readers through metaphoric language. For instance, reaching the train station, Jim Burden narrates: "[T]he engine was panting heavily after its long run"(Cather,1994(1918): 34). The engine, an inanimate object, is personified and given a humanlike quality which is breathing. Similarly, Jim Burdens extends his description of the landscape and the Prairie using a pictorially metaphorical language: 
I felt that the grass was the country, as the water is the sea. The red of the grass made all the great prairie the color of winestains, or of certain sea weeds when they first washed up. And there was so much motion in it; the whole country seemed...to be running. (42)

Cather's use of the rhetorical trope of synecdoche is apparent. She uses the part "grass" to refer to the whole "the country", and "water" to refer to the "sea". Moreover, the landscape is described as a living thing; the description evokes a physical and visual sensation, as the landscape is personified as a human being making motion and running. Like Virginia Wolf, Cather projects herself imaginatively on her male character. She could see things from the point of view of her narrator. Once asked why she used Jim Burden's point of view in $M y$ 'Antonia, her answer was: "I've been practicing by writing McClure's autobiography, and people wrote to me and said this was McClure himself speaking, and I thought I could pull it off. I think that is a valid explanation, but not the real one" (Faulkner and Slate,1977: 232). She may have employed the point of view of a male character to broaden her range of content.

My 'Antonia revolves around Antonia Shimerda and Jim Burden through the eyes of Jim as he narrates the main bulk of the events reminiscing his memories as a child till he becomes a youth at the end. In the introduction to My 'Antonia, Cather distances herself from Jim, presenting him as "a separate boy person with a 'romantic disposition' which makes him seem a very funny boy" (Murphy,1974: 98). Since he is too much involved in the events, he seems to be, to a great extent, a participant in the events and an unreliable narrator. The question that comes to mind is: why does Cather employ visual drawings in $M y$ 'Antonia since we agree that she is against ornament and that every word in her own fiction is written to serve a specific purpose? In fact, almost every character depicted and every drawing inserted in the text add to the overall structure of the plot. Developing Henry James' notion 
of hierarchy among readership, Cather suggests that "the best element in the most laudable of art[...] be appreciated only by a certain class of people, capable of understanding the language of artists"(Vanderlaan,2011: 15-16).

Cather's My Antonia comprises eight plates of WT Benda's drawings which Cather herself chooses their specific places in the novel. These drawings are not merely to decorate; they serve a function since they are not identical with Jim's account of the scenes portrayed. Each drawing provides a parallel picture story in My Antonia. Each drawing reflects a subtext that reveals other interpretation beyond Jim's narration. Sometimes the line drawing consolidates what he narrates, other times the drawing contradicts his narration. According to Joseph Urgo, these illustrations constantly remind readers that there are "alternative perspectives"(Urgo,2003: 29). Though words dominate the text of Cather, visual art plays an enormous role in the novel. In a way, Cather must have intended to shed doubt on Jim's account. She may want to confirm that there are many possibilities for each story and they are different interpretations for each account. Each account is susceptible to various perspectives and no one can have the whole truth within reach. According to James Carney, "no theory of representation can be fully convincing unless it accommodates or explains our intuition that not any picture can represent or depict anything" (Carney, 1981:179).

In Cather's My Antonia, the novel is replete with dominating words, yet there are eight successive visual images that have an important role in the novel. The first drawing of Benda is inserted in the first chapter of Cather's My Antonia; it captures the narration of the protagonist Jim Burden, orphaned and newly transplanted to his grandparents' farm, in his train trip to Nebraska. In Jim's narration, "a group of people stood huddled together on the platform, encumbered by bundles and boxes... The woman wore a fringed shawl tied over her head...There was an old man, tall and stooped. Two half-grown boys 
and a girl stood holding oil-cloth bundles, and a little girl clung to her mother's skirts"(Cather,1994[1918]: 34).

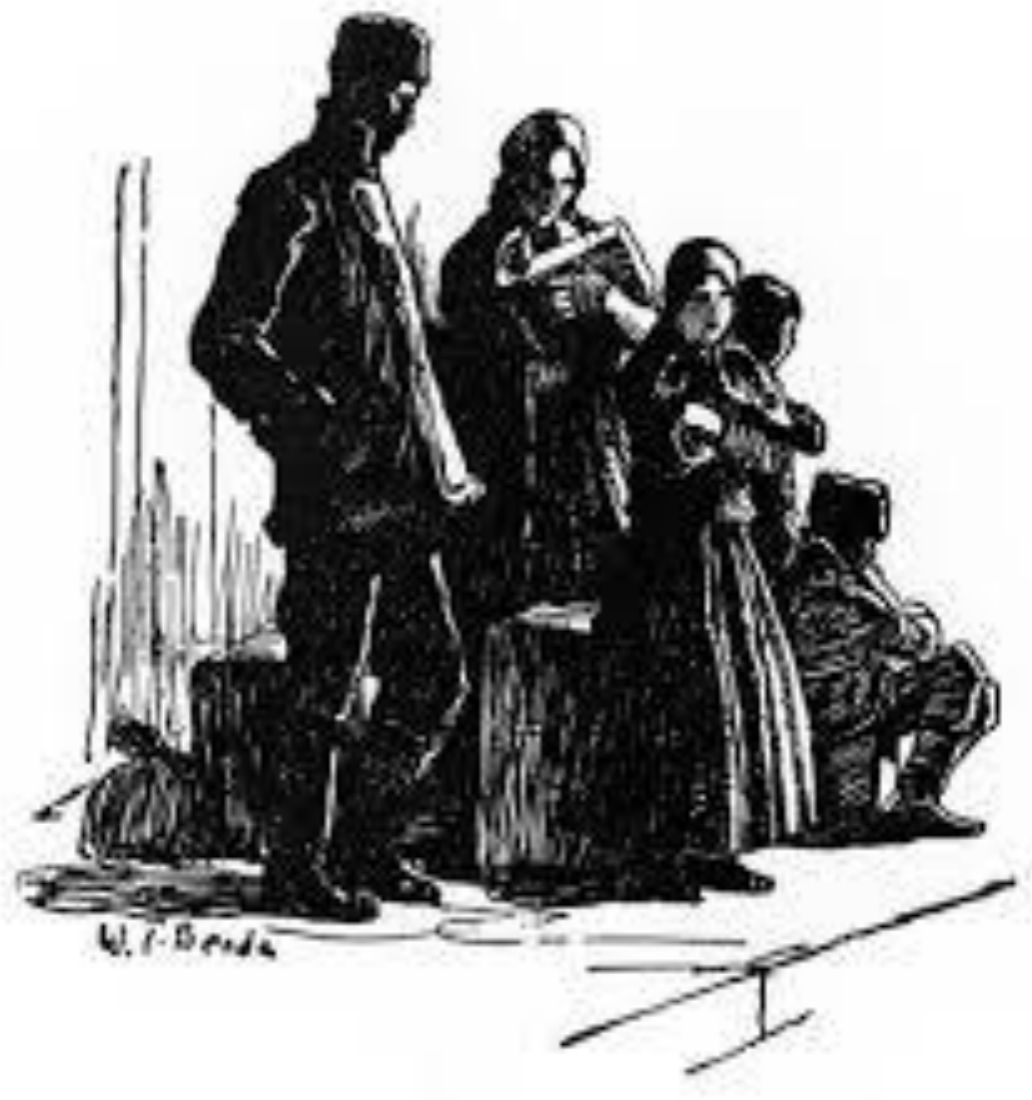

Line Drawing (1) of My Antonia: The Shimerdas Family

The drawing depicts different generations telling the story of a blood line. It shows the immigrant Shimerdas family arriving in Nebraska on the train platform. We see, much as Jim has narrated, the Shimerdas are waiting among their bundles. Taking into consideration that the "images of the human body and its gestures are the principal bearers of meaning" (Mitchell,1995: 27), this family portrait drawing has a narrative quality to it. Considering Ludwig Wittgenstein's saying "the human body is the best picture of the human soul", the father-in this drawing-gazes downward, a sign of his dissatisfaction and discouragement. His space in the drawing is darkened more than the others, signifying his new burdens of responsibilities in the New Land. 
He is mostly surrounded by jaggedly freehand lines, which have expressive quality, signifying turmoil and anxiety on the part of the head of the family. Yet, these lines are broken to indicate ephemerality because the man will live a short span of time. At the same time, these lines include thin ones g expressing delicacy on his part since the man is talented and plays the violin.

Central focus is on the mother; she appears to be grasping a box as if she were hugging a newly born baby. Readers know that she has no babies, yet the way she holds her box shows that it is a treasured property of her past life and that she treasures possessions. It is she who insists that her family move to America where opportunity is much greater. In the textual content, she says: "America big country [sic]; much money, much land for my boys, much husband for my girls"(Cather,1994[1918]: 96). She uproots her family against her husband's wish from their homeland and friends. Now she is going to live a new story in the New Land at the time she is clinging to the past. Readers are encountered with huge discrepancies with what is narrated and what is seen, an affirmation to Wittgenstein's famous words "what can be shown cannot be said".

The girl, Antonia, whose brown eyes will be celebrated, is "as bright as a new dollar"( Cather,1994[1918]: 34). In Benda's drawing, she does not hold her mother's dress as Jim claims in the narration, still she gazes out, clasping her hands, which is a sign of independence, determination and shouldering responsibilities. When Jim first meets Antonia, he is impressed by her eyes which are" big and warm and full of light, like the sun shining on brown pools in the wood. Her skin [is] brown, too, and in her cheeks she ha[s] a glow of rich, dark color. Her brown hair [is] curly and wild-looking"(Cather,1994[1918]: 47). One gets a pictorial portrait of Antonia through Jim's vivid narration. By associating external light with Antonia from the beginning of the novel, Cater enhances the physical qualities of the character. 
Contrary to Jim's narration, Antonia's two younger brothers, too, are clasping their hands, holding nothing. There is something misleading about the picture as being analogous to the narration. No one is holding oil-cloth bundles although there is a bundle on the ground behind the stooped man. While one of the boys is standing huddled his sister for warmth, the other is sitting down on one of the family's bundles in a trance. The drawing also reveals no eye contact between all the members of the Shimerdas family, foreshadowing the idea of different experiences and different perspectives in the New Land. At the feet of the family members, except for Mr. Shimerdas, there are two horizontal lines suggesting the long distance that they have to pass.

In the textual context, describing Mr. Shimerda, Jim writes that he along with Antonia, now becoming friends, saw a figure moving on the margin of hilly land with "a gun over his shoulder. He was walking slowly, dragging his feet along as if he had no purpose"(Cather, 1994[1918]: 60).

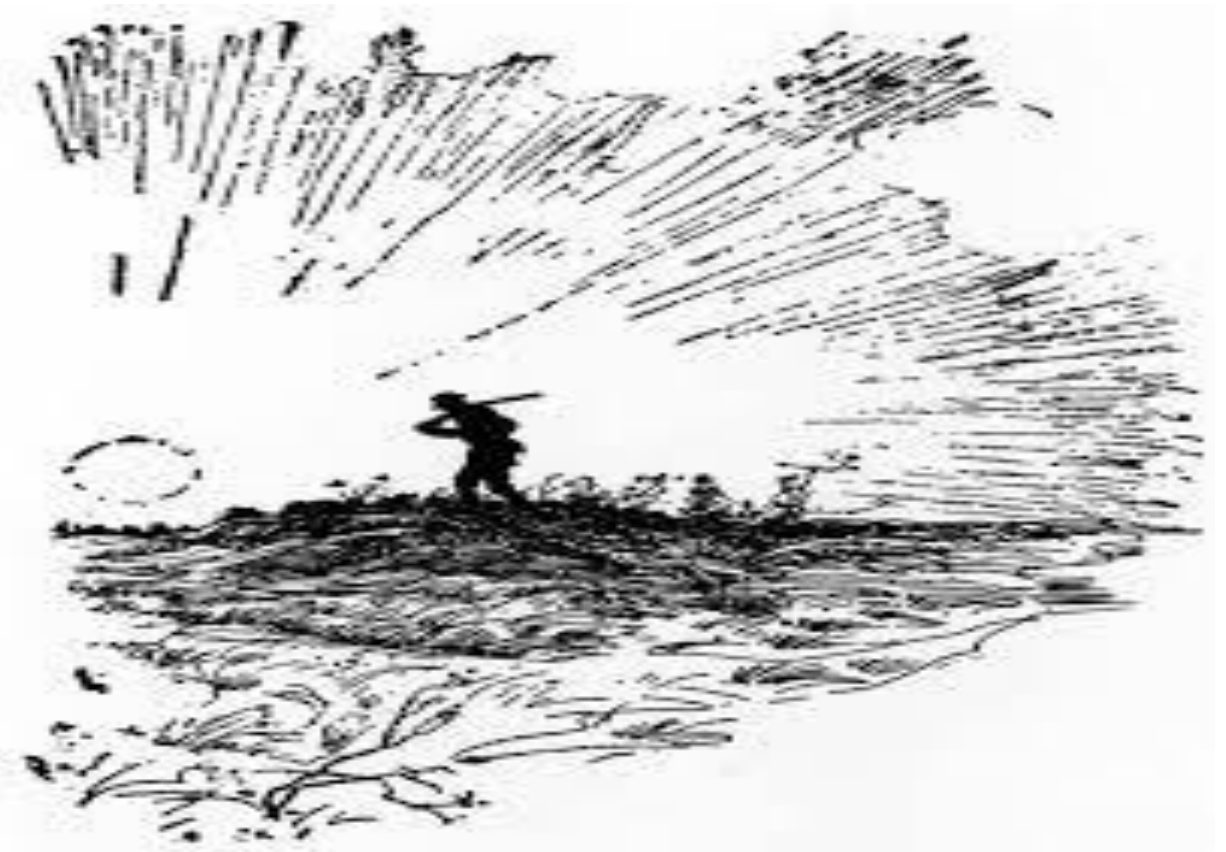

Line Drawing 2 of My Antonia: Mr. Shimerda with his Rifle 
On the other hand, Benda's second drawing which appears in the sixth chapter of Cather's My Antonia reveals half a circle, showing in the center Mr. Shimerda, tall and thin, with bent head. Yet, he steadily walks towards the sun, as if the man actually knows what he wants and is determined to move towards it, and not dragging his legs as Jim proclaimed in his narration. His present case compared with his comfortable past is the reason behind his present condition. The drawing shows determination and bravery as he tries to survive on his family's hope in the American dream. Benda's half circle is significant; it signifies Mr Shimerda's short span of life in the New Land.

The man's social self-the public self of the father and husband - is what makes him leave his country. Leaving his former life in the country he loved takes the spirit out of Mr. Shimerda. He left Bohemia, where he made a good living and was well respected. In the New Land, he leads a life that does not satisfy his private needs. He is neither content nor happy. According to Jim: The man's "face look[s] like ashes-like something from which all the warmth and light had died out"(Cather,1994[1918]: 48). Benda's painting gives readers a visual reflection of the spacious grasslands and the vastness of the new land's sky in which the sun is sinking. The drawing shows curved lines on the ground, referring to grass. It also shows long straight lines at the top, referring to the spacious sky. The big circle down in the drawing refers to the sinking sun which sends its rays up to the spacious sky. The man is ambitious heading towards achieving prosperity for his family. He suffers a double life which he cannot endure. His split-self results in living a life and aspiring for a totally different one. When he fails, Mr. Shimerda commits suicide. 
In the textual context, Mrs. Shimerda gave Mrs Burden, Jim's grandmother, some dried mushrooms, a treasure brought from Bohemia. Yet, what Mrs. Shimerda treasures highly has no value at all to the American. Mrs. Burdens is disgusted when receiving such a gift. She does not know what it is and throws it out. Here, differences in culture are noticeable in terms of what people eat.

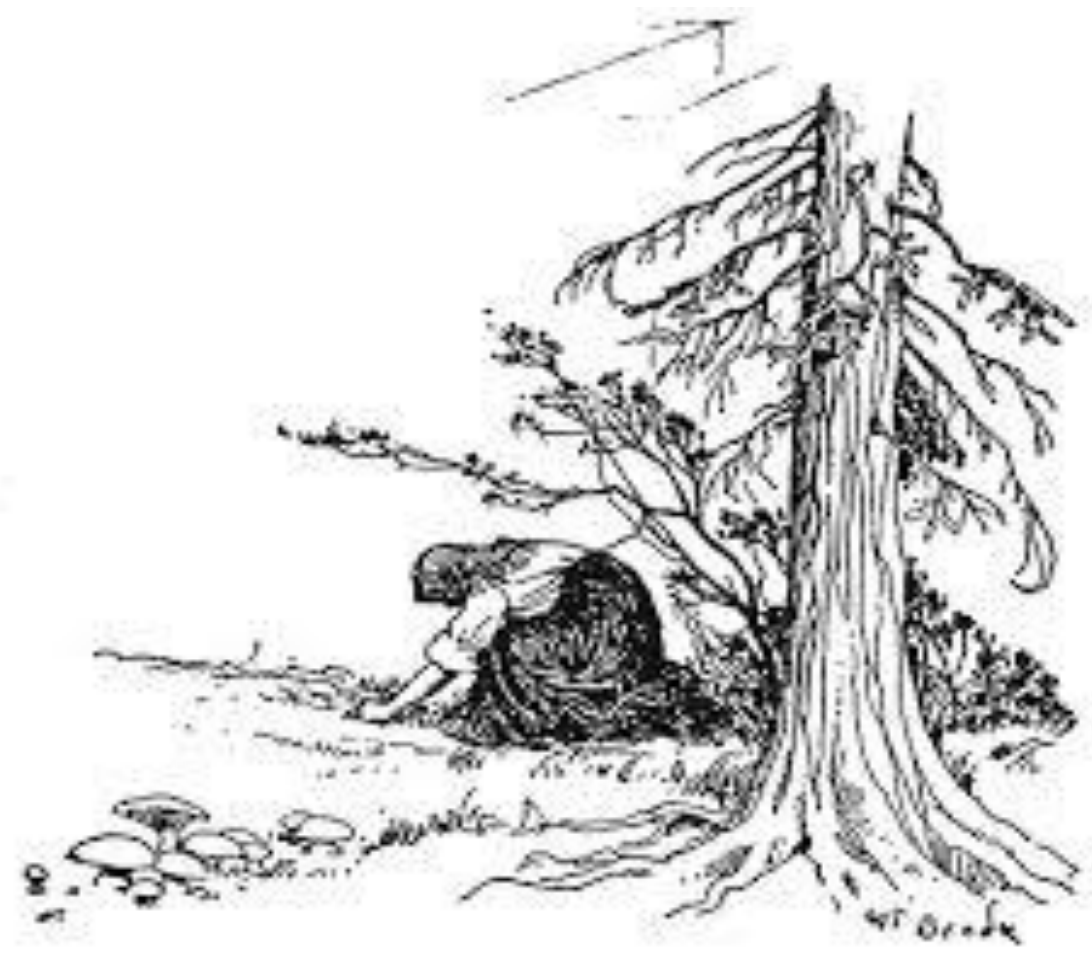

Line Drawing (3) of My Antonia:

A Bohemian girl collecting Mushrooms

Nothing in the picture makes it reasonable to say it represents the situation which actually obtains-Mrs Shimerda giving Mrs Burden a gift. Benda's drawing regarding this incident, located in chapter $\mathrm{X}$, is generalized somehow. Regarding Wittgenstein's theory of picture representation, the drawing does not represent the text; it is an inaccurate representation of the narration as it is not a picture of the incident at all. Yet, it echoes the incident, showing a young woman, 
not Mrs. Shimerda, whose sleeves are pushed back and rolled up; she goes down to work on the land gathering mushrooms in Bohemia. A cluster of mushrooms are obviously seen in the drawing. A leafless old huge tree is on the foreground. Though the novel starts with the immigrant family in Nebraska, and Cather never pictures them back in their homeland, the drawing reflects nostalgia of the homeland, something Jim cannot refer to as an American narrator. The Shimerdas are still clinging to memories of their past. Through this drawing, Cather creates memorable scenes and significant setting. Such a setting denotes the Shimerdas' tormenting feeling of leading double lives, a theme Cather discusses. Through Line Drawing (3), one can see the importance of the visual representation and the textual one to the complete meaning of the structure of the imagetext in Cather's $M y$ 'Antonia.

The fourth drawing emerges in chapter XII, and it shows a man, alone, riding a horse and returning with a Christmas tree. With an absolutely remarkable minimalism, the line drawing reveals a void rural area, an empty narrow trail, and some weeds. The broad clear sky is shown by a blank sheet of paper. 


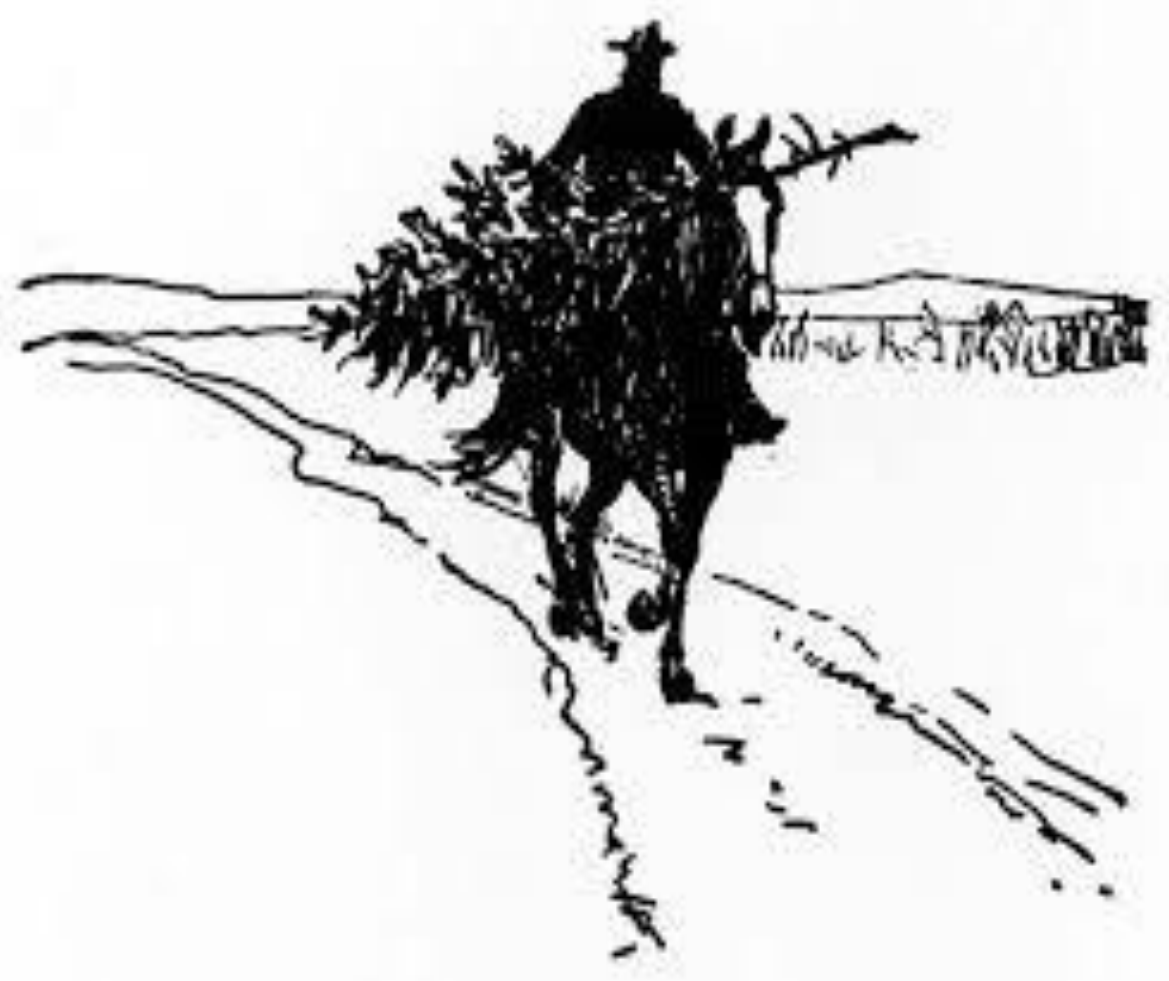

Line Drawing (4) of My Antonia:

A man Riding a Horse and holding a Christmas tree

In Cather's narrative, Jim narrates that it is Christmas time and Jakes, the hired man, is supposed to go to the town, Black Hawk, to sell the family's Christmas presents. Yet, it snows so much that it is decided that he will not go. Ambrosch, the Shimerdas' son, goes to cut the Christmas tree with Jakes. According to Jim's painterly narration: "It was a soft gray day outside, with heavy clouds working across the sky, and occasional squalls of snow" (Cather,1994[1918]: 91). There are no signs of clouds nor showers of snow in the drawing; on the contrary there is an emptiness all over the place. As readers, we assume a huge discrepancy between what is narrated and what is depicted in the drawing. It is as if Cather is saying not all stories you hear should believe, shedding light to the unreliability of her narrator. 
After the inexplicable and unexpected suicide of Mr. Shimerda in winter - may be a last final plea for helping his family-Antonia decides that she has to take care of her family herself. The fifth drawing, coming out in chapter XVII, shows another broad cloudy sky. In this particular illustration, the elements depicted are magnified and the whole scene is zoomed in. I think Cather intends to magnify this scene as she gets the plate lowered on the page. Such a scene appears focused so to create a sense of clear observation and direct presence. The place is shown all over empty. There is a sharp central focus on the plough, the horses, the heavy horse collar, and Antonia herself. According to Jim's narration:

[S]he brought her horses up to the windmill to water them. She wore the boots her father had so thoughtfully taken off before he shot himself, and his old fur cap. Her outgrown cotton dress switched about her calves, over the boot-tops. She kept her sleeves rolled up all day, and her arms and throat were burned as brown as a sailor's. Her neck came up strongly out of her shoulders, like the bole of a tree out of the turf. One sees that draft-horse neck among the peasant women in all old countries. (117) 

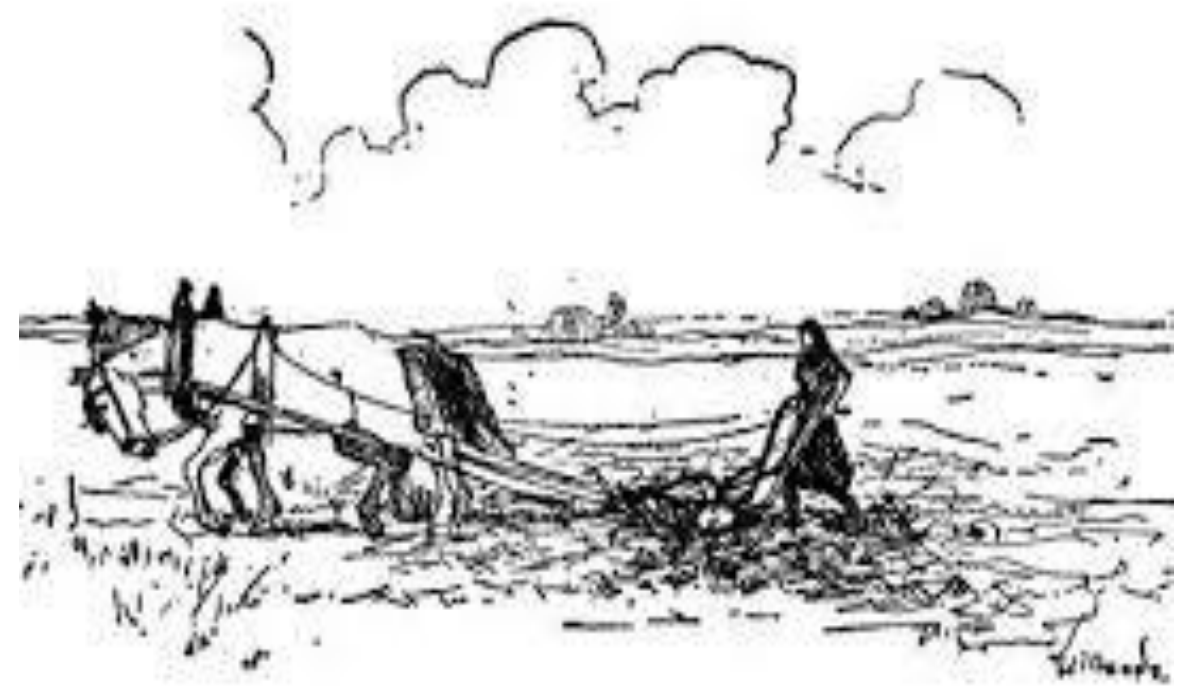

Line Drawing (5) of My Antonia: a woman ploughs

We see, much as Jim would have narrated, Antonia is now busy working in the fields. A strong young scarf-headed girl, she ploughs the fields. The image of the plough is magnified in the drawing. This agricultural equipment is magnified to symbolize the way of life. Cather decreases the amount of space around the plough to affect the way we view the object. Instead of giving us piteous social victims who are comical figures who cannot speak English in a foreign country and are with ridiculous accents, Cather gives us a forceful heroine who tills the soil alone, values books and learning, and negotiates the alien culture. According to Morris Dickstein(1999: 20), Cather navigates new worlds in literature and arts, showing adventurous independent minds. Though abandoned with a child, Antonia survives and manages to bring her children up. Like Cather herself, Antonia is an immigrant who grew up in the prairie. She experiences hunger and faces many obstacles in her life. By the end of the novel when Jim visits Antonia after a long lapse of years, he notices that she has "not lost the fire of life" and that her "inner glow" has not faded (Cather,1994[1918]: 264). Though it is indicated in Jim's narration paralleling the above drawing 
that it is summer, the drawing shows a visibly cloudy sky. It also shows Antonia's sleeves rolled up, but never shows her naked neck. it shows her scarfed head covering her neck. The drawing minimalized Jim's portrayal of Antonia.

The sixth drawing, protruding in chapter XVII, is reminiscent of the second, with its sunrays. In this case, it shows a close up details with the striking sun that will magnify the plough on the horizon. According to Jim's narration,

Each morning, while the dew was still on the grass, Antonia went with me up to the garden to get early vegetables for dinner. Grandmother made her wear a sunbonnet, but as soon as we reached the garden she threw it on the grass and let her hair fly in the breeze. (Cather,1994[1918]: 128-129)

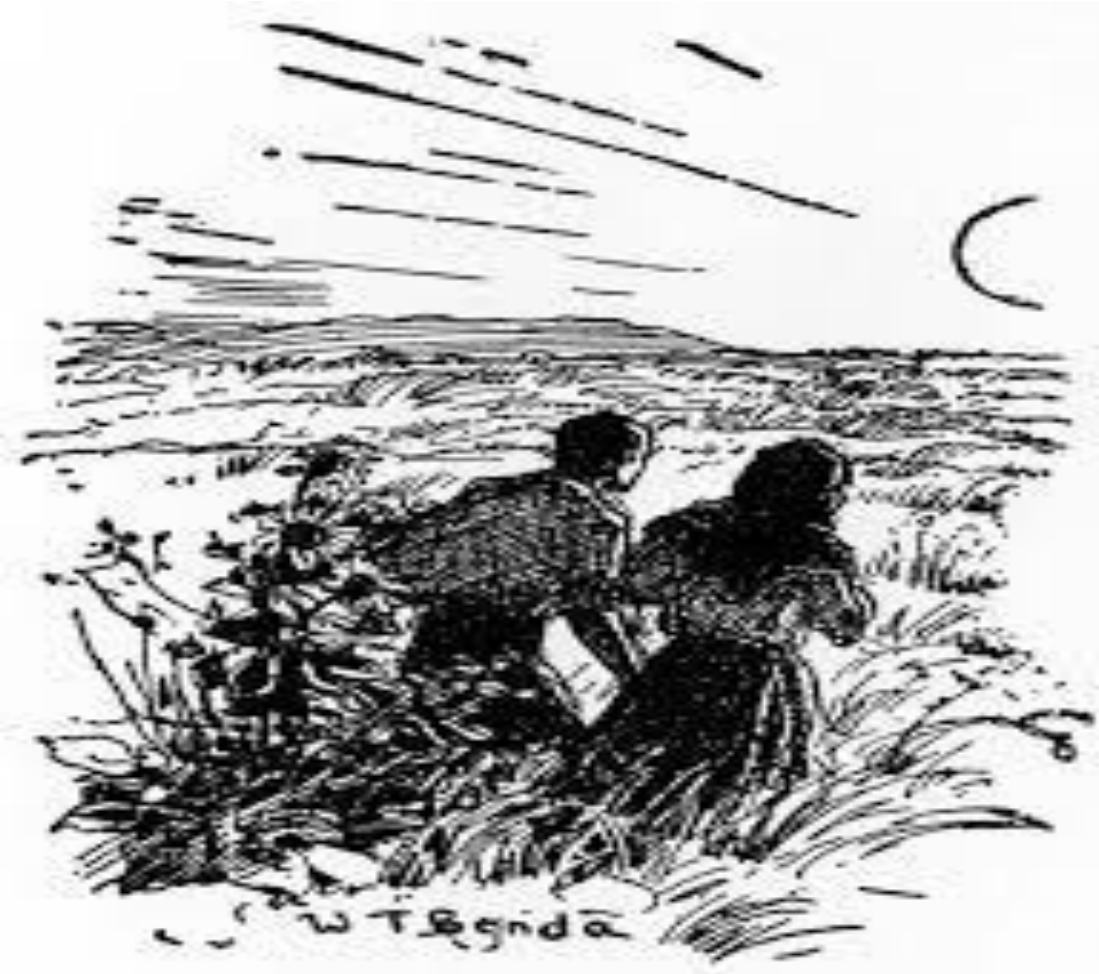

Line Drawing (6) of My Antonia: Jim and Antonia Picnic in prairie 
There is an apparent analogy between Jim's words and the picture. We see companionable young people, a head scarf implying immigrant identity, and one sunflower plant. This drawing shows intense energy and depicts close-up details in a rather empty prairie. Jim demonstrates that his childhood friend, Antonia, and he picnic for the last time when the vision disappears and the sun sets.

[T] hat forgotten plough had sunk back to its own littleness somewhere on the prairie.... It was July. The burning sun of those few weeks, with occasional rains at night secured the corn.... The men were working so hard in the wheat fields they did not notice the heat. (Cather,1994[1918]: 128)

The drawing indicates a heroine showing physical vitality with a young man and are on a stroll. There is an open circle in the sky indicating the rising sun which is often associated with Antonia. Also some straight horizontal lines are up in the sky indicating distance and calmness of the wide horizons. We have many stories within the main story of Antonia and Jim's friendship.

The seventh drawing, featuring in Book II chapter IV, shows another big summer sky with the merest indication of cumulus clouds. The drawing is mainly focused on a female's physique as it shows her wild nature since she lived on the prairie. Jim's description of Lena's wild nature goes as follows: "The swelling lines of her figure had been hidden under the shapeless rags she wore in the fields" (Cather,1994[1918]: 152). 


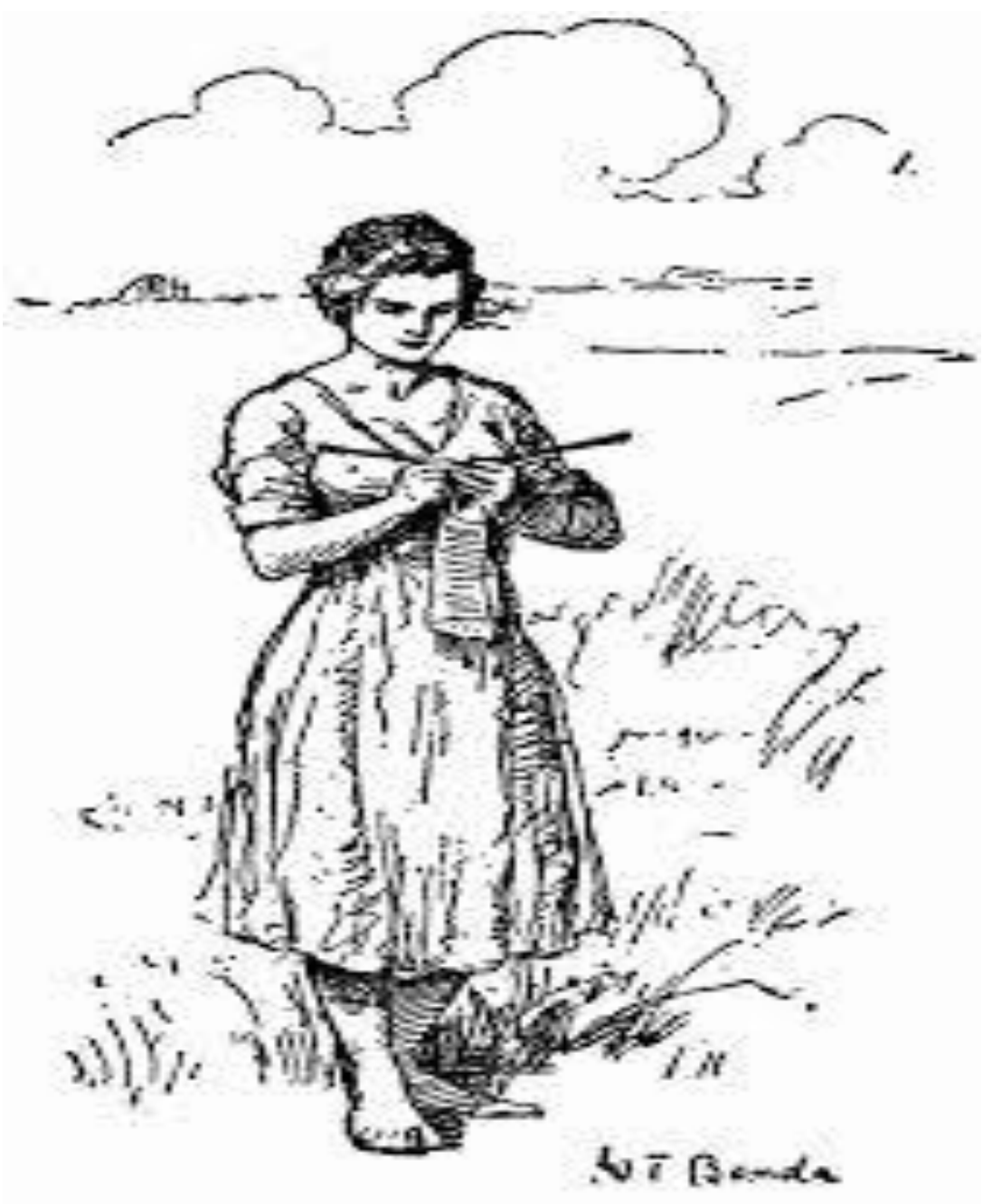

Line Drawing (7) of My Antonia: Lina Lingard

Jim's narration about Lina Lingard, the embodiment of extraordinary beauty, holds a great deal of truth to Benda's drawing. She is an immigrant hired girl from the countryside, working as a dressmaker. In the line drawing, Lina's two knitting needles and the rows of her knitting are clearly seen, along with her. There is indeed a clear focus on the physique of Lena- her bare feet, her uncovered blonde hair, her rolled up sleeves, her starkly bare neck coming strongly out of her shoulders. She appears in a slinky tight-fitting dress. However, not only is she indifferent to men being attracted to her, but 
also she does not want to get married at all and she ends up a successful designer in San Francisco. In the drawing, Cather criticizes Lena as she is fairly bursting out of her clothes. Yet, she delineates an important aspect in the novel which is dual life.

The eighth drawing, standing out in Book IV chapter III, the last in the series of illustrations in Cather's novel, starkly shows Antonia struggling through the snow into the wind. Jim sees her "driving her cattle homeward across the hill"(Cather,1994[1918]: 251). She holds a whiplash in her right hand, wearing what Jim calls "a man's long overcoat and boots, and a man's felt hat"(251). The dark coat, hat, and boots, and the bent position of her head to avoid snow, are reminiscent of the first picture, of the Shimerdas waiting on the train platform. A single line outlines the top of the cloud, closing in the top of the picture.

Again this line drawing captures the emptiness of the prairie, which is Cather's significant setting. While the setting is in focus, other great details in the drawing are separated: snow in the air is flying around Antonia, tracks she treads, the whip she holds in her hand. It is another masterful example of minimalist design executed with line techniques reminiscent of woodcuts, an indication of the innovative techniques of Cather's art. 


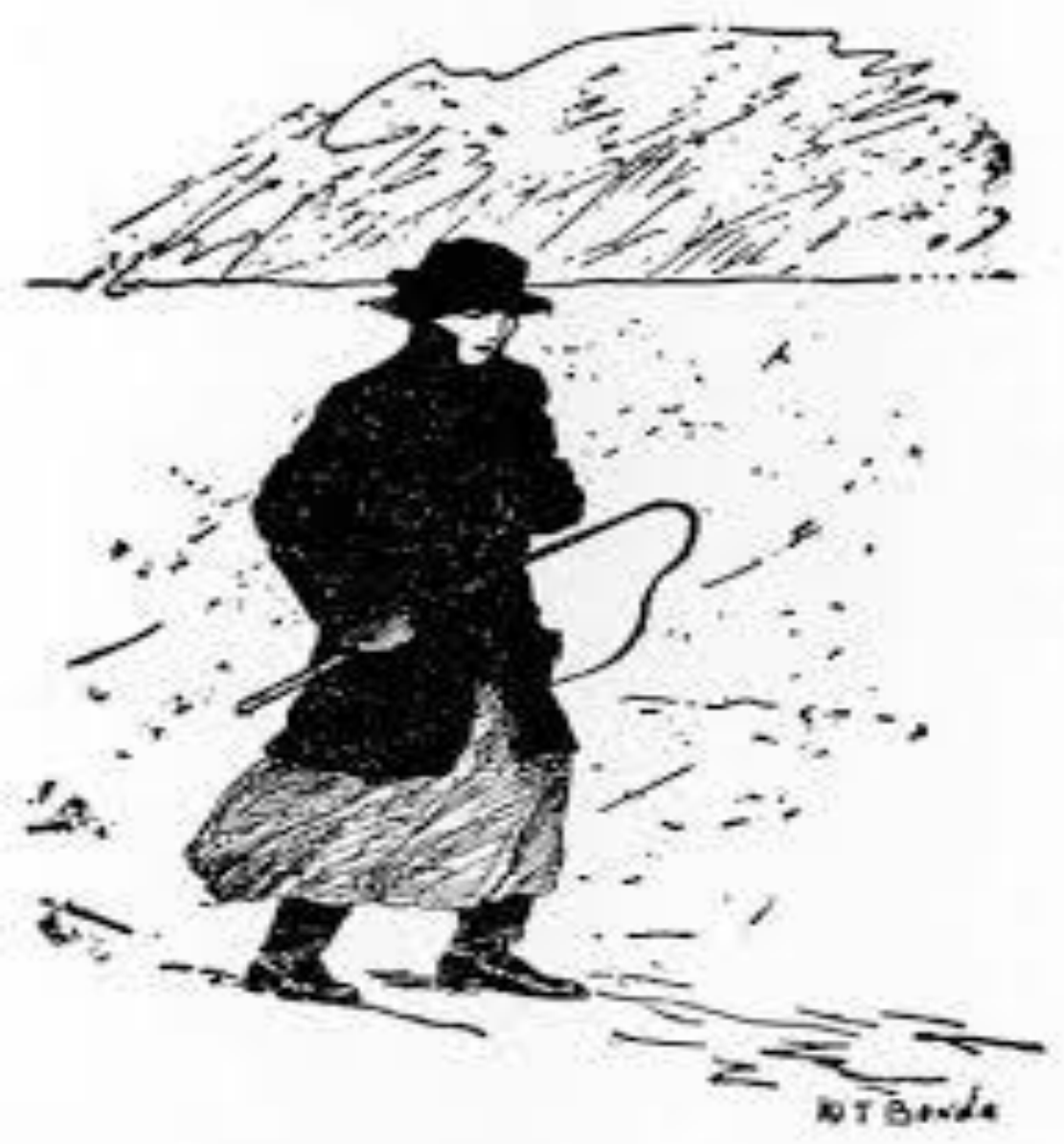

Line Drawing (7) of My Antonia: Antonia holding a whip

Yet, in Benda's drawing Antonia's skirt is clearly visible. Her face shown under the hat is feminine and she does not appear mannish as Jim claims in his narration. On the day she will give birth to her illicit baby, Antonia drives her cattle downward across the hill. She appears outside her prescribed role as she is making her way through society. She proves to be a strong willed woman throughout the most difficult moments in her life. When her lover, Larry Donovan, leaves her high and dry, she comes back home unmarried, disgraced and pregnant. Yet, she, silently, works hard once more in the farm alone like men till the day she gives birth to her baby girl. Unlike Lina Lingard who is the embodiment of physical sexuality and who ignores men and marriage, Antonia who cares for social conformity falls in 
love with the wrong person and he leaves her high and dry. Having a baby daughter born outside wedlock, Antonia is not ashamed of her. She is determined to help her have better chances than her mother ever had. She takes a picture of her baby daughter and buys an expensive frame for the picture, never minding what the people say about her. She is so self-confident that she defies social conventions when having a baby outside marriage.

All images in the novel prove to be para-textual elements used to comprise a social code, that comes from the outside of the text, and a textual code that is governed by the text itself. As a result, there comes to be several readings for the same text depending on the change in the social, cultural and historical background that present different readings of the images, and consequently of the whole work. There is a strong persistent "tie between the text and the para-text[sic]" (Norledge, 2020). Cather's use of spatial structures, lines, forms, and shapes establishes her in the community of art and helps her innovate authorial techniques. This, in a way, enables her to embrace a wider range of suggestions and meanings, interpreted by her readers. Regarding Wittgenstein's theory of picture representation, some of Benda's drawings do not represent the text. His thesis of strong isomorphismthe utter analogy between expression and picture-is somehow disregarded. Yet, the pictures somehow echo the incidents, showing a mild co-operation between text and image to create a multilayered text with multiple perspectives. Cather uses physical forms, whether these forms or shapes in space are two-dimensional or three-dimensional. Through her use of art, drawing, juxtaposition, suggestions and framing techniques, Cather manages to engage her readers and let them use their minds and voice their different ideas and interpretations. They share in constructing meanings. She lets them share in producing the meaning of the text. She addresses a special type of readers, one who is very insightful. According to Cather, the language of artists is limited and confined only to certain readers who can absorb the things not said or not named. She does not impose the perspective of one specific 
narrator on the character or the event. She lets her characters tell their own stories.

To conclude, Cather's drawings create parallel stories to her novel. They are considered a second author to My Antonia. They provide a framework of interpretative meanings. The eight pictures inspire different reactions as they do not show strong isomorphism. They are neither ornamental nor structural designs. They strengthen the readers' capacity of constructing communicative meaning to the text. Cather uses images to add more meanings and perspectives to her fictional work and to warn readers against taking everything for granted. She suggests the presence of multiplicity of sides to every story. She provides readers with an alternative story of the same incident. She wants to confirm that there are many sides and different facets for each story and that no one can ever know the whole truth, an indication to the duality of lives the characters lead. Thus, she sheds doubt on Jim's reliability as a narrator, something which Cather intends to reveal by her commissioning such eight plates from WT Benda and her placing them in their specific places in My Antonia. In a word, Cather employs visual art in her novel to disclaim authorial narration and to indicate the duality of lives the characters lead in a modern age. 


\section{Works Cited}

1. Bloom E and Bloom L (1962) Willa Cather's Gift of Sympathy. Carbondale: Southern Illinois U P.

2. Carney J (1981) Wittgenstein's Theory of Picture Representation: TheJournal of Aesthetics and Art Criticism 40(2): 179-185.

3. Carrier D(2003) Writing About Visual Art. New York: Allworth Press.

4. Cather W (1922) The Novel Démeublé: The New Republic, pp. 5-6.

5. Cather W (1949) Preface. The Best Stories of Sarah One Jewett.vol.1, New York, pp. XI-XIX.

6. Cather W(1988) On Writing: Critical Studies on Writing as an Art. Lincoln\& London.

7. Cather W(1994[1918]) My Antonia: Sharon O'Brien Intro. USA: Signet,

8. Dickstein M (1999) The Magic of Contradictions: Willa Cather's Lost Lady: New Criterion 17(6): 12-20.

9. Genette $G$ and Maclean M (1991) Introduction to the Paratext: New Literary History 22(2):261-272.

10. Genette G (1997) Paratext: Thresholds of Interpretation. Cambridge:Cambridge U P.

11. Hoggart R (2020[1994]) A Measured Life: The Times and Places of an Orphaned Intellectual, Routledge.

12. Kaufman AL and Millington RH (2015) Willa Cather and Nineteenth Century. Lincoln and London: $U$ of Nebraska.

13. Leddy M (2009) Distant and Correct: The Double Life and The Professor'sHouse. In: Jewel

14. A (ed.) Cather Studies. vol.3. The Willa Cather Archive, pp.1-9.

15. Lundquist B (1999) Wittgenstein and Aesthetics: What is the language of Art". Gustavus Adolphus College

16. Mitchell WJT(1995) Picture Theory: Essays on Verbal \& Visual Representation. Chicago\&London: University of Chicago Press.

17. Murphy J (1974) Five Essays on Willa Cather: The Merrimack Symposium. North Andover, Massachusetts: Merrimack College 
18. Norledge $\mathrm{J}$ (2020) Building the Ark: Text World Theory and the evolution of dystopian epistolary Language and Literature, pp.1-19

19. O'Brien S (1994) Introduction: Willa Cather's My Antonia. USA: A Signet Classics.

20. Onega S (2006) Structuralism and Narrative Poetics. In: Waugh P (ed.) Literary Theory and Criticism: An Oxford Guide. New York: Oxford U P, pp.259-279.

21. Petersen R (2011) Comics, Manga, and Graphic Novels. Praeger.

22. Read H (1968) A Concise History of Modern Painting. Frederick A. Praeger.

23. Rosowski S J (1990) Recent Books on Willa Cather: An Essay Review. MFS Modern Fiction Studies 36(1): 131-141.

24. Schwind J (1985) The Bends Illustrations to My Antonia: Cather's "Silent" Supplement to Jim Burden's Narrative. PMLA 100(1): 51-67.

25. Slote B and Faulkner V (1977) The Art of Willa Cather. Lincoln\& London: U. of NebraskaP.

26. Stout J P (2007) Picturing a Different West: Vision, Illustration, and the Tradition of Austin and Cather. Texas Tech U P.

27. Urgo J R (2003) My Antonia by Willa Cather. Canada: Broadview Literary Texts.

28. Vanderlaan K (2011) Sacred Spaces, Profane Manufactories: Willa Cather's Split Artist in

29. The Professor's House and My Mortal Enemy. Western American Literature 46(1): pp. 15-16.

30. Wittgenstein L and Anscombe G. E. M (1986 [1958]) Philosophical Investigation. Oxford, UK: Basil Blackwell.

31. Woodres J (1987) Willa Cather: A Literary Life. USA: U of Nebraska P. 